\title{
Implementation of Document Management System using Levenshtein Distance Algorithm
}

\author{
Diky Firdaus \\ Faculty of Computer Science \\ Universitas Mercu Buana \\ JI. Meruya Selatan No. 1, Jakarta 11650
}

\author{
Yuwan Jumaryadi \\ Faculty of Computer Science \\ Universitas Mercu Buana \\ Jl. Meruya Selatan No. 1, Jakarta 11650
}

\begin{abstract}
The document archiving in PT SIU is still manually so it takes a long time in the process of storing and searching an archive document. Document Management System is a process or activity that starts from the making, receiving, collecting, organizing, controlling, maintaining, maintaining and storing which can be used as a solution in order to solve the problems that occur. With this research, previously manual storage and search became computerized so that the process of storing and searching for information related to document archiving systems became easier, and faster.
\end{abstract}

\section{Keywords}

Archive, Document Management System, Analysis and Design

\section{INTRODUCTION}

In this era, the use of technology is more advanced [1][2]. Archives are records of activities or sources of information in various forms created by the institution. Document management system is a process or activity that starts from the creation, acceptance, collection, regulation, control, maintenance, maintenance, and storage and evaluation according to certain system standards [3][4]. The increasing amount of documentation is a problem for the institution because it requires more space, energy and time in its management, and also the use of archives can cause loss of documentation.

The levenshtein distance algorithm is a matrix used to measure the difference between the two sequences. The edit distance calculation is obtained from a matrix used to calculate the number of differences between two strings [5].
The usage of Levenshtein algorithm, because this method can manage the string with the concept of alteration, addition, deletion, and can measure the difference in two strings.

\section{LITERATURE REVIEW}

\subsection{Digital Document Management System}

Digital Document Management System is a collection of digital documents composed systematic and consistent manner that can be used to store digital documents, subjectoriented, integrated, and time variant. DMS is generally supported by the conceptual data model that can be used to view history data of an object activity for analysis and reporting purposes. DMS is used to overcome the problems of the common mistakes that is the inconsistency of document management information, a discrepancy of data between documents and document physical damage [3]. The usage of DMS is to reduce the amount of office space and filing cabinets that are not comparable to the growth for the document.

\subsection{Algorithm of Levenshtein Distance}

The algorithm of levenshtein distance is metrics to measure the difference distance between two sequences. Edit distance calculations obtained from the matrix which is used to calculate the amount of the difference between the two strings. The calculation of the distance between two strings is determined from the minimum number of changes to make the string operation into the B string Levenshtein A distance between two strings is determined based on a minimum number of changes/edits necessary to carry out the transformation of one form of string into another form of string [6]. 


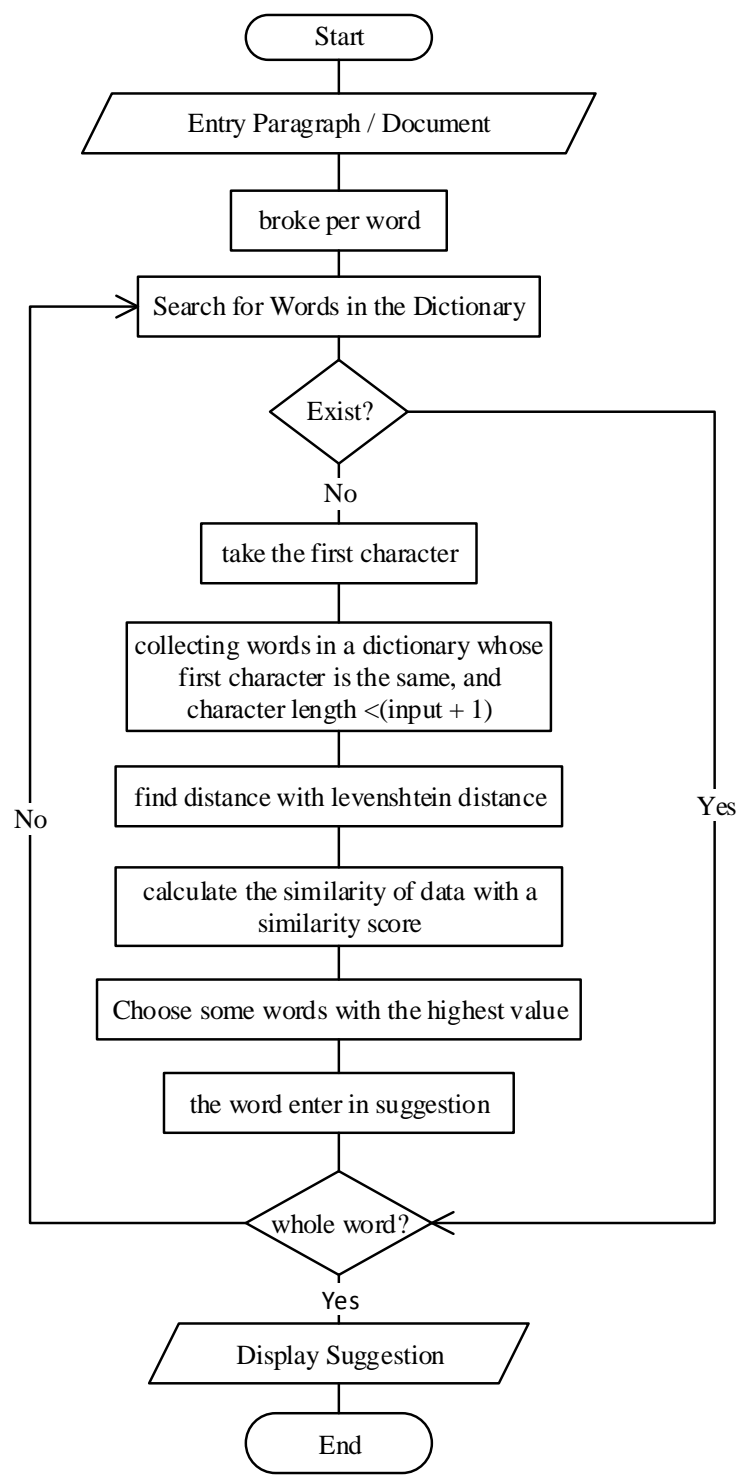

Fig 1: Levenshtein distance Algorithm.

Based on previous research that uses Levenshtein Distance Algorithm, to correct the spelling has $86 \%$ of accuracy rate, and to know the structure of the sentence has $76.66 \%$ of accuracy rate. In that study, this method is quite accurate in spelling correction, but in parsing the sentence structure is still less accurate.

\section{RESEARCH METHODOLOGY}

This application uses the methodology of Software Development Life Cycle (SDLC), which is the process of developing or changing a software system as well as the models and methodologies used to develop a software system. One fmodel that is owned by the SDLC is a waterfall Model [7], that consists of 4 steps:

1. Analysis of System

Analysis is the stage of system research and data collection in accordance with needs.
2. Implementation

This stage designs the system according to needs and performs and determines the process of how the system works in terms of architechture design, interface design, database and file specifications, and program design.

3. Implementation.

At this stage, the researcher builds an application based on the "blueprint" design.

\section{4. $\quad$ Testing}

This stage, performs all the application functions to be free of errors, and the results must be completely in accordance with the requirements that have been previously defined.

\section{RESULANTS AND DISCUSSION}

\subsection{Business Processs}

Researchers mapping the business processes in PT SIU, as a blueprint system to be created. As shown in Figure 2 


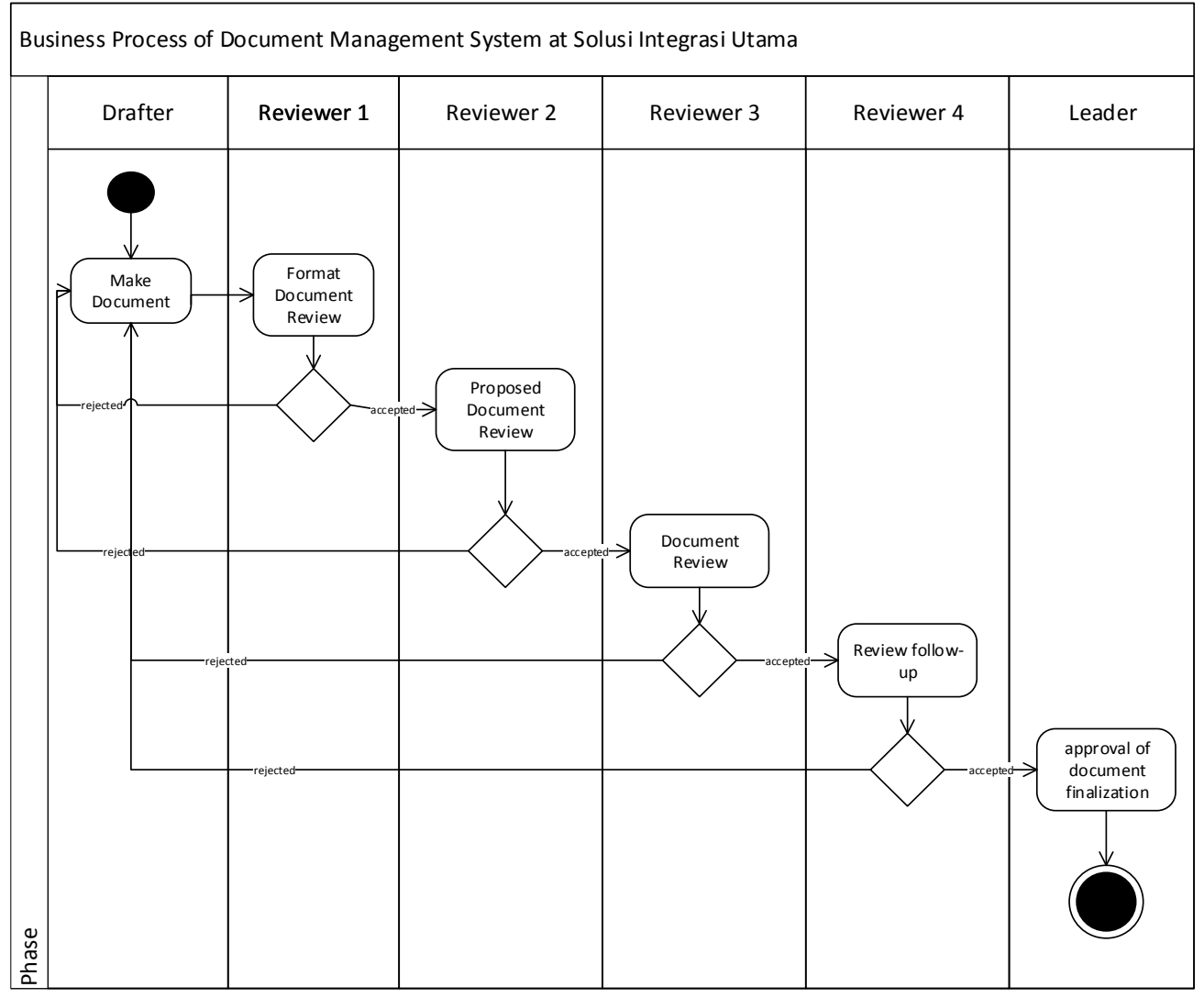

Fig 2: Business Process

In this mailing blueprint Procedure of the System, there are several users are involved, such as the drafter, Reviewer, and leaders. Drafter would make mailing accordance with SOP office. Reviewers 1 Will review the format of document that have been made by Drafter, is in accordance with the SOP Rules mailing office property. Reviewers 2 reviewing the Proposed documents that have been made by the drafter. Reviewers 3 reviewing the document, if it is in accordance with the SOP at office, then it will continue to Reviewers 4 to Follow-Up to the document. The leader approves the finalization of the document, if the document is feasible, then the document can be forwarded to the customer.

\subsection{Use Case Diagram}

Use case diagrams are used to design system activities. Use Case Diagram is a diagram that contains use cases, actors, relationships [8]. Use Case Diagram is a modeling for information system behavior that will be created. In accordance with its function, Use Case diagram is an interaction between one or more actors with the information system to be made, and as a limitation of a system that will be created.

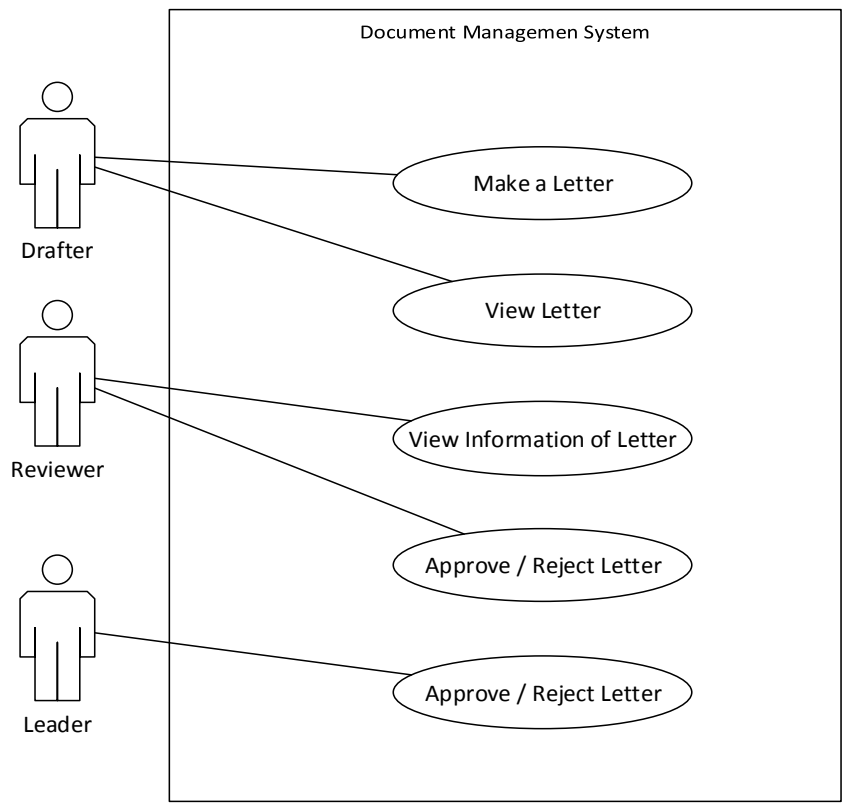

Fig 3: Use Case Diagram 


\subsection{Activity Diagram}

Researchers mapping the business processes in PT SIU, as a blueprint system to be created. As shown in Figure 2.

\subsubsection{Activity Diagram of Drafter}

Drafter who want to create a document should be login first. After login successfully, then a drafter can make documents on the website as in figure 4 .

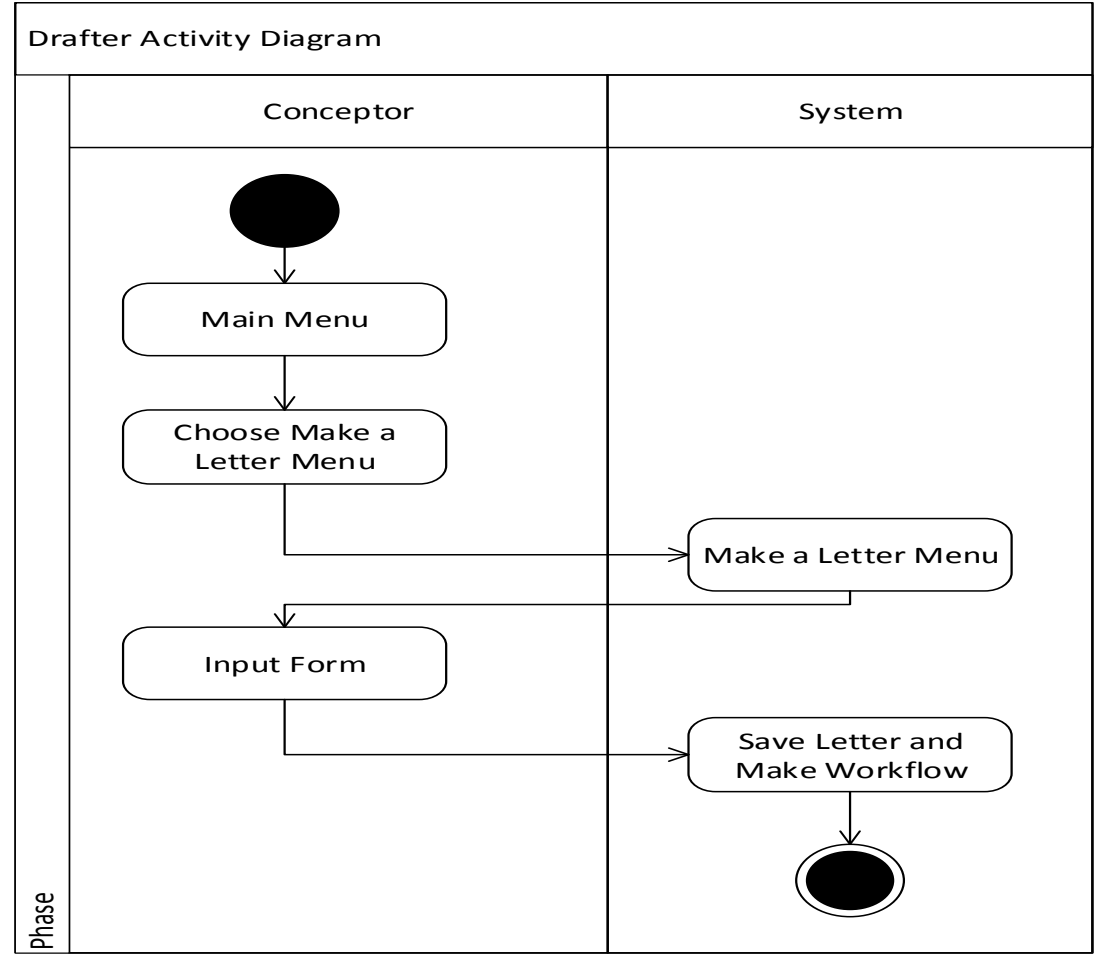

Fig 4: Activity Diagram of Drafter

\subsubsection{Activity Diagram of Reviewer}

Reviewers should login first by enter username and password. Reviewers can Reject or Approve the existing documents. The
Reject document will be returned to the drafter, and the approve document will be followed by the system to the leader.

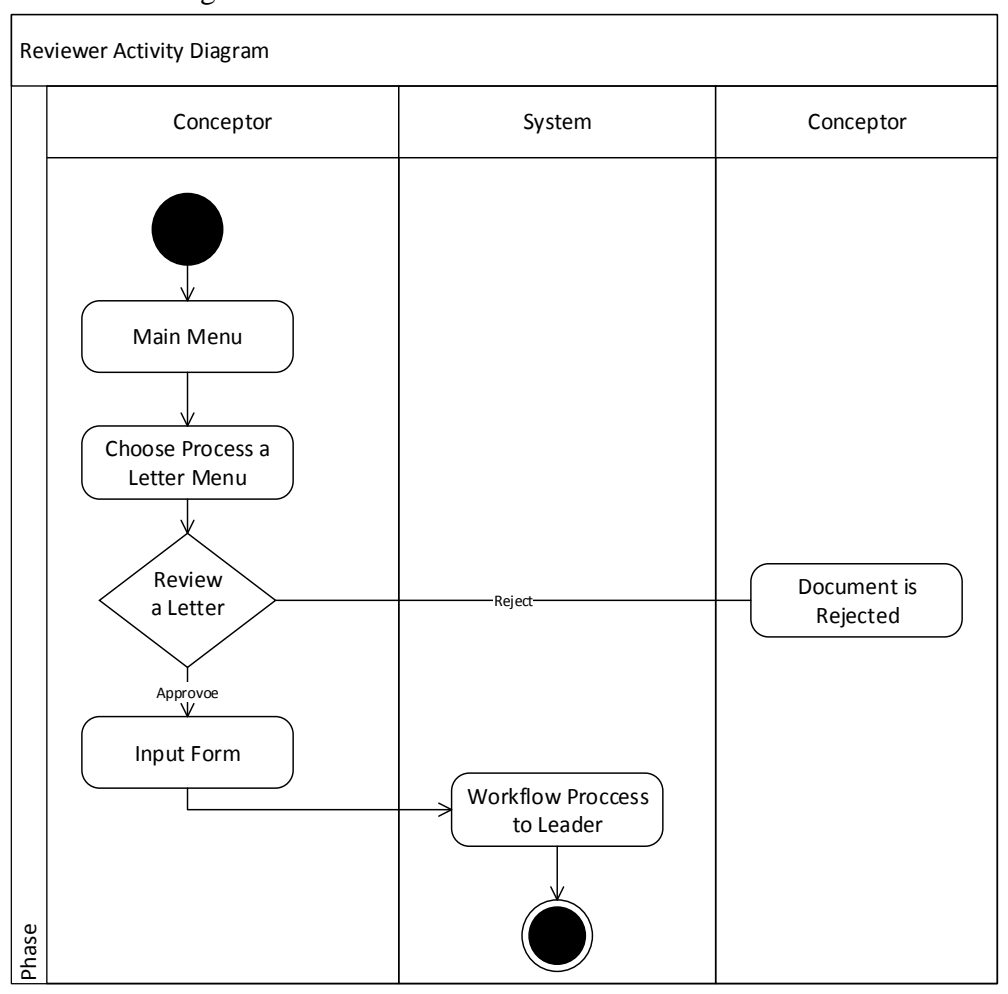

Fig 5: Activity Diagram of Reviewer 


\subsubsection{Activity Diagram of Leader}

Leaders should login first by enter username and password. Leaders reviewing documents that have been approved by the reviewer. Leaders can Reject and Aprrove the documents. If the documents rejected, then the documemnt will returned to the drafter, and vice versa if the document is approved then the drafter can download and print the document.

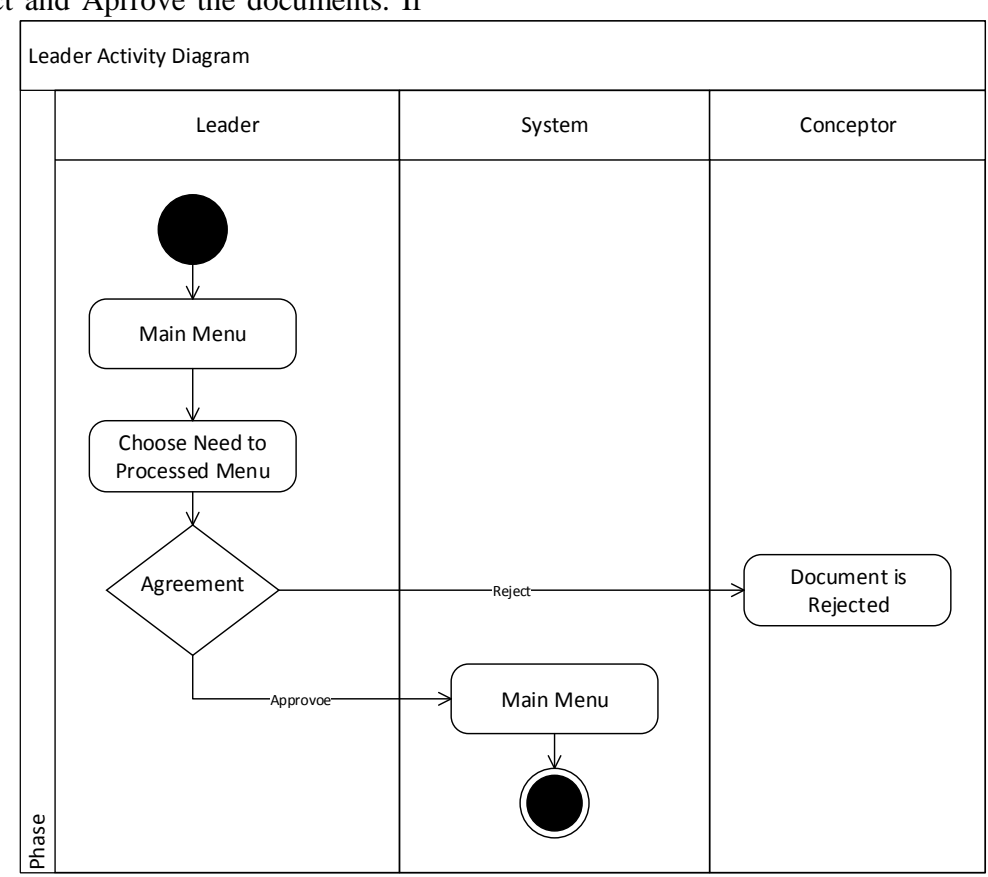

Fig 6: Activity Diagram of Leader

\subsection{Implementation}

\subsubsection{Menu of Upload Documentation}
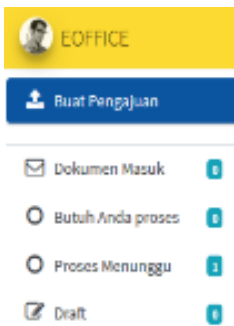

(-) Dokumen Selesai

L keluar
On the Document Upload Page, users can upload documents into DMS. Users can save documents into the draft if the document doesn't want to be uploaded.

Fig 7: Page of Document Upload

\subsubsection{Menu of Incoming Document}

Incoming Documents page is a menu where users receive
Reject and Approve documents. Documents can be seen at Incoming Documents. 


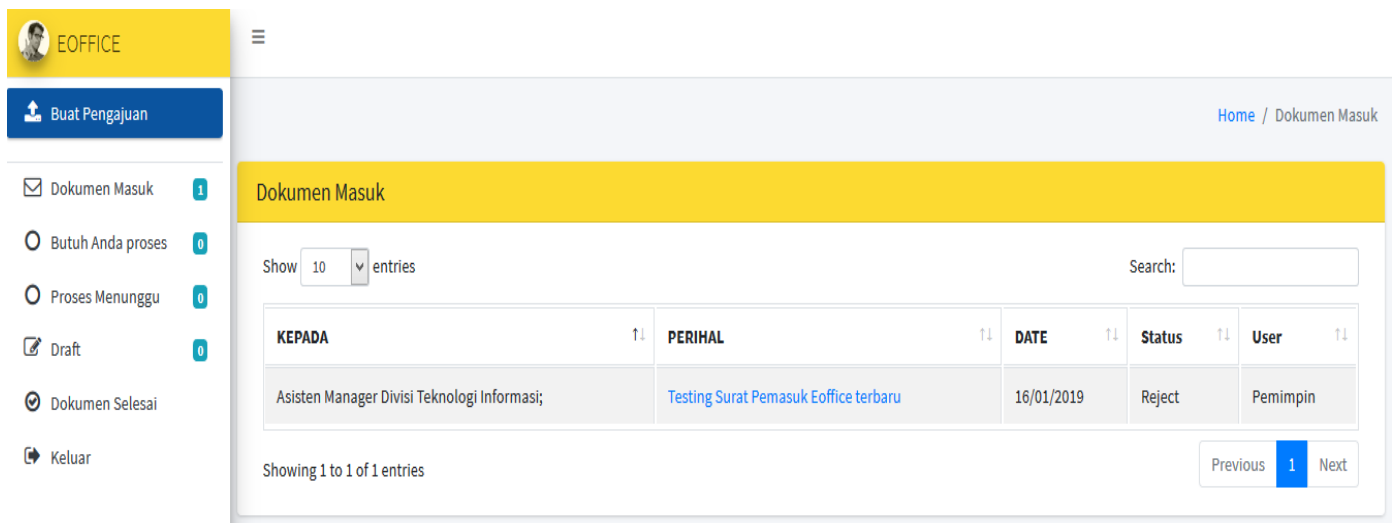

Fig 8: Page of Incoming document

\subsubsection{Menu of Document Process Detail}

Page of Documents Process Detail is a menu where the user can see the information of document, and the user can view the document stage of the process.

\section{Q EOFFICE $\quad \equiv$}

t. Buat Pengajuan

$\square$ Dokumen Masuk 1

Butuh Anda proses 0

O Proses Menunggu 0

6 Dratt

(†) Dokumen Selesai

$\hookrightarrow$ Keluar

0
Dokumen Masuk

Show $10 \quad \vee$ entries Search:

KEPADA

Asisten Manager Divisi Teknologi Informasi,

1. PERIHAL

Testing Surat Pemasuk Eoffice terbaru

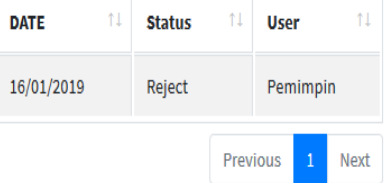

Fig 9: Page of Document Process Detail

\subsubsection{Menu of Finish Document Process}

display the documents that already process.

The page of finish document Process is a page that

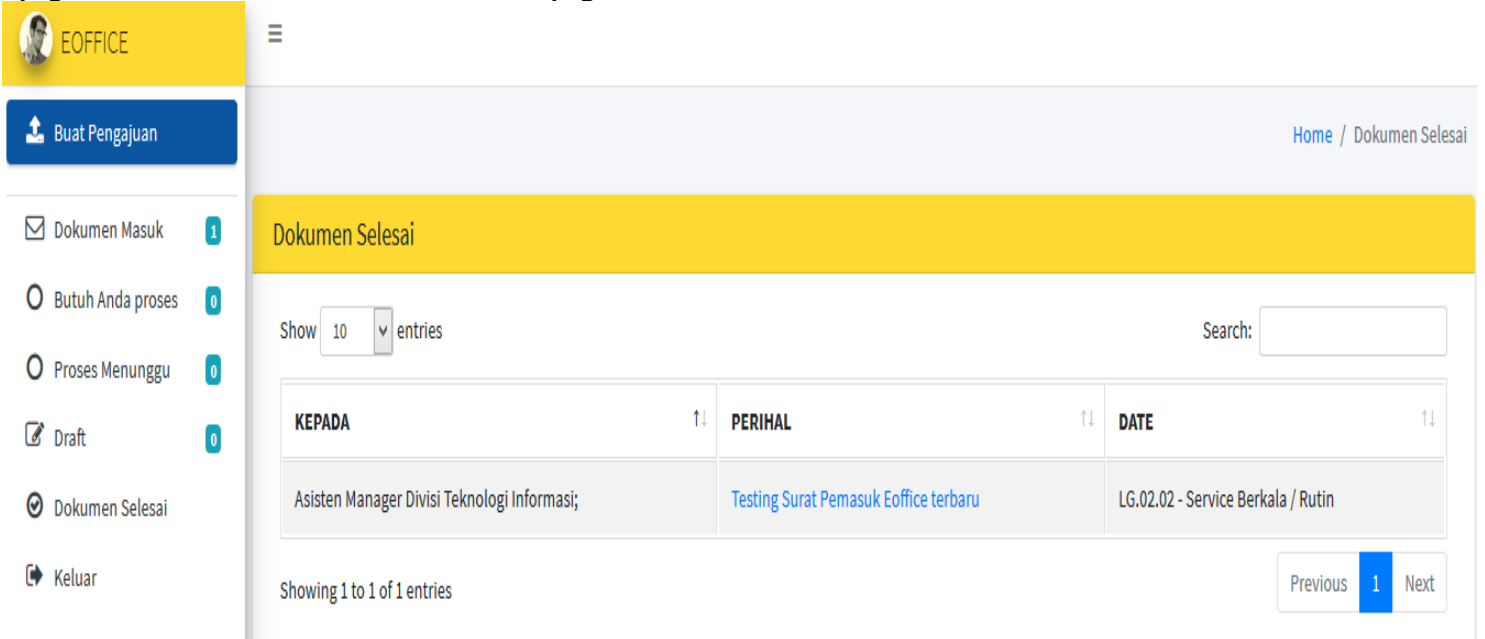

Fig 10: Page of Finish Document Process

\subsubsection{Testing}

The next step is testing the system that has been implemented. Testing is done to ensure that all functional requirements of the system run as expected using the black box method. Black box is a test that focuses on functional specifications of software. Table 1 is the result of testing in this system.
Table 1. Testing Result

\begin{tabular}{|c|c|c|}
\hline Test Case & Expected results & Status \\
\hline $\begin{array}{c}\text { Experimenting } \\
\text { on the } \\
\text { application } \\
\text { menus }\end{array}$ & $\begin{array}{c}\text { The menu in the application } \\
\text { displays information that } \\
\text { matches the workflow } \\
\text { created }\end{array}$ & Valid \\
\hline
\end{tabular}




\section{CONCLUSION}

With a documentation management system that has been developed, companies can make electronic management of documents and distributed through a system that is documented automatically when creating documents. The system that has been developed has provided a solution to the problems that occur in the company.

\section{REFERENCES}

[1] Y. Jumaryadi and B. Priambodo, "Deteksi Wajah Terkejut Menggunakan Eigenfaces," J. Ilm. Fasilkom, vol. 6, no. 2, pp. 83-90, 2017

[2] A. E. Husin, T. D. Soehari, Y. S. Prabowo, and Zulfiqar, "Analytical hierarchy process (AHP) implementation in determining document evaluation criteria of post qualification E-tendering knockout phase," Int. J. Eng. Adv. Technol., vol. 8, no. 6, pp. 160-165, 2019, doi: 10.35940/ijeat.E6925.088619.

[3] S. P. Nugroho, O. S. Simanjuntak, and F. R. Kodong, "Pengembangan Document Management System Untuk Pengelolaan Sumur Minyak di PT. Geotama Energi," Telematika, vol. 12, no. 1, pp. 63-67, 2015.
[4] S. Farik et al., "Electronic Document Management System: Malaysian Experience," Aust. J. Basic Appl. Sci., vol. 9, no. 3, pp. 82-89, 2015.

[5] S. Rani and J. Singh, Enhancing Levenshtein's Edit Distance Algorithm for Evaluating Document Similarity, vol. 805. Springer Singapore, 2018

[6] Z. Afriansyah, D. Puspitaningrum, and Ernawati, "Rancang Bangun Aplikasi Penccocokan DNA Manusia Menggunakan Algoritma Levenshtein Distance (Studi Kasus : DNA Kanker Hati Manusia)," J. Rekursif, vol. 3, no. 2, pp. 61-67, 2015.

[7] A. Siddieq and I. Nurhaida, "Mobile application of BTS tower search build upon location based service (LBS)," Libr. Hi Tech News, vol. 36, no. 3, pp. 1-6, 2018, doi: 10.1108/LHTN-08-2018-0049.

[8] Paech B., "On the role of activity diagrams in UML-a user task centered development process for UML," Lect. Notes Comput. Sci. (including Subser. Lect. Notes Artif. Intell. Lect. Notes Bioinformatics), vol. 1618, pp. 267277, 1999, doi: 10.1007/978-3-540-48480-6_21. 